\title{
The Frequency, Penetrance and Variable Expressivity of Dilated Cardiomyopathy-Associated Putative Pathogenic Gene Variants in UK Biobank Participants
}

\author{
Running title: DCM Genotype-First Approach in the UK Biobank
}

Ravi Shah, MB BChir ${ }^{1, *} ;$ Babken Asatryan, MD, $\mathrm{PhD}^{2, *}$; Ghaith Sharaf Dabbagh, $\mathrm{MD}^{3,4}$; Nay Aung, $\mathrm{MD}^{5,6}$; Mohammed Y Khanji, MBBCh $\mathrm{PhD}^{5,6,7}$; Luis R. Lopes, MD, $\mathrm{PhD}^{5,8}$; Stefan van Duijvenboden, $\mathrm{PhD}^{6}$; Anthony Holmes ${ }^{9}$; Daniele Muser, $\mathrm{MD}^{10}$; Andrew P. Landstrom, MD, $\mathrm{PhD}^{11}$; Aaron Mark Lee, BSc(hons), PhD, MBBS ${ }^{5,6}$; Pankaj Arora, MD ${ }^{12}$; Christopher Semsarian, MBBS, PhD, $\mathrm{MPH}^{13,14,15}$; Virend K. Somers, MD, $\mathrm{PhD}^{16}$; Anjali Owens, $\mathrm{MD}^{17}$; Patricia B Munroe, MSc, $\mathrm{PhD}^{6}$; Steffen E. Petersen, MSc, MPH, MD, DPHil ${ }^{5,6}$; C. Anwar A. Chahal, MBChB, PhD, MRCP ${ }^{3,5,10,16}$

1. Imperial College Healthcare NHS Trust, London, UK

2. Department of Cardiology, Inselspital, Bern University Hospital, University of Bern, Bern, Switzerland

3. Center for Inherited Cardiovascular Diseases, WellSpan Health, Lancaster, PA, USA

4. University of Michigan, Division of Cardiovascular Medicine, Ann Arbor, MI, USA

5. Barts Heart Centre, St Bartholomew's Hospital, Barts Health NHS Trust, London, West Smithfield, EC1A 7BE, UK

6. NIHR Barts Biomedical Research Centre, William Harvey Research Institute, Queen Mary University of London, EC1A 7BE, UK

7. Newham University Hospital, Barts Health NHS Trust, London E13 8SL, UK

8. Centre for Heart Muscle Disease, Institute of Cardiovascular Science, University College London, London, UK

9. GE Healthcare, Chicago, IL, USA, retired

10. Cardiac Electrophysiology, Cardiovascular Division, Hospital of the University of Pennsylvania, Philadelphia, PA, USA

11. Departments of Pediatrics, Division of Cardiology, and Cell Biology, Duke University School of Medicine, Durham, NC, USA

12. Division of Cardiovascular Disease, University of Alabama at Birmingham, AL, USA

13. Agnes Ginges Centre for Molecular Cardiology at Centenary Institute, The University of Sydney, Sydney, New South Wales, Australia

14. Sydney Medical School Faculty of Medicine and Health, The University of Sydney, Sydney, New South Wales, Australia

15. Department of Cardiology, Royal Prince Alfred Hospital, Sydney, New South Wales, Australia

16. Department of Cardiovascular Medicine, Mayo Clinic, Rochester, MN, USA

17. Center for Inherited Cardiovascular Disease, Cardiovascular Division, University of Pennsylvania Perelman School of Medicine, Philadelphia, PA, USA

Drs. Shah and Asatryan contributed equally and are co-first authors.

Article category: Original research article

Total word count: 4525

Number of tables and figures: 7

Journal Subject Terms: Cardiomyopathy; Genetics; Sudden Cardiac Death

\section{Address for Correspondence:}

C. Anwar A. Chahal, MBChB, MRCP, PhD

Center for Inherited Cardiovascular Diseases

WellSpan Health

140 North Pointe Blvd., Lancaster, PA 17601

Phone: (717) 291-0700; Fax: (717) 291-0700

Email: DrAChahal@ doctors.org.uk; anwar.chahal@pennmedicine.upenn.edu 
It is made available under a CC-BY-NC-ND 4.0 International license .

\section{ABSTRACT}

Background: There is a paucity of data regarding the phenotype of dilated cardiomyopathy (DCM) gene variants in the general population. We aimed to determine the frequency and penetrance of DCMassociated putative pathogenic gene variants in a general, adult population, with a focus on the expression of clinical and subclinical phenotype, including structural, functional and arrhythmic disease features.

Methods: UK Biobank participants who had undergone whole exome sequencing (WES), ECG and cardiovascular magnetic resonance (CMR) imaging were selected for study. Three different variant calling strategies (one primary and two secondary) were used to identify subjects with putative pathogenic variants in 44 DCM genes. The observed phenotype was graded to either 1) DCM (clinical or CMR diagnosis); 2) early DCM features, including arrhythmia and/or conduction disease, isolated ventricular dilation, and hypokinetic non-dilated cardiomyopathy; or 3) phenotype-negative.

Results: Among 18,665 individuals included in the study, 1,463 (7.8\%) subjects possessed $\geq 1$ putative pathogenic variant in 44 DCM genes by the main variant calling strategy. A clinical diagnosis of DCM was present in $0.34 \%$ and early DCM features in $5.7 \%$ of individuals with putative pathogenic variants. ECG and CMR analysis revealed evidence of subclinical DCM in an additional $1.6 \%$ and early DCM features in $15.9 \%$ of individuals with putative pathogenic variants. Arrhythmias and/or conduction disease (15.2\%) were the most common early DCM features, followed by hypokinetic non-dilated cardiomyopathy (4\%). The combined clinical/subclinical penetrance was $\leq 30 \%$ with all three variant filtering strategies. Clinical DCM was slightly more prevalent among participants with putative pathogenic variants in definitive/strong evidence genes, as compared to those with variants in moderate/limited evidence genes.

Conclusions: In the UK Biobank, approximately $1 / 6$ of adults with putative pathogenic variants in DCM genes exhibited a subclinical phenotype based on ECG and/or CMR, most commonly manifesting with arrhythmias in the absence of substantial ventricular dilation/dysfunction.

Key Words: cardiomyopathy; genetics; ventricular arrhythmia; sudden cardiac death; genetic testing; biobank; penetrance 


\section{Clinical Perspective}

What is new?

- Among individuals with putative pathogenic DCM gene variants, subclinical DCM and early DCM features, detected by ECG and/or CMR, were nearly four times more common than clinically manifest DCM or early features (23.7\% vs. $6.1 \%)$.

- Over $90 \%$ of subjects with a putative pathogenic variant in DCM-associated genes did not have a prior history of DCM.

- Clinical DCM was slightly more prevalent among participants with putative pathogenic variants in definitive/strong evidence genes (13.9\% for clinical and subclinical), as compared to those with variants in moderate/limited evidence genes, but there was no significant difference in combined clinical/subclinical phenotype by cluster.

- The overall clinical/subclinical penetrance of DCM-associated single putative pathogenic variants was highly variable between genes, ranging from 0 to $66.7 \%$.

What are the clinical implications?

- Arrhythmias and cardiac conduction disease are the most common early manifestation of putative pathogenic variants implicated in DCM, mostly occurring prior to the development of structural/functional abnormalities.

- A genotype-first screening approach for DCM using a large genetic panel is currently not suitable in the general population due to incomplete understanding of DCM genetic architecture and reduced penetrance of DCM-associated putative pathogenic variants. 


\section{INTRODUCTION}

Dilated cardiomyopathy (DCM) is a genetic heart disease that frequently leads to end-stage heart failure, characterized by progressive left ventricular (LV) or biventricular dilation and impaired contraction that is not explained exclusively by abnormal loading conditions (hypertension or valvular heart disease) or coronary artery disease. 1 Patients with DCM often present in adulthood and are prone to life-threatening ventricular arrhythmias, with 30\% dying suddenly. 2 With the advent of next-generation sequencing technologies, there has been a dramatic increase in the number of genes tested and variants identified in patients with DCM. $\underline{3}$ To date, over 250 genes from ten gene ontologies have been reported in association with DCM, of which only 19 were recently found to have moderate, strong, or definitive evidence for causality in monogenic DCM by Clinical Genome Resource (ClinGen) DCM Gene Curation Expert Panel. $\underline{4}$ Currently, it is estimated that a pathogenic or likely pathogenic variant can be identified in approximately $20-35 \%$ of patients with DCM. $\underline{5}$ 므

The increasing availability, falling costs, and widespread use of genetic testing (including directto-consumer testing) offer an opportunity to use a 'genome-first' method for diagnosis. $\underline{7}$ However, routine genetic screening is not currently justified because of the unknown frequency of putative pathogenic DCM gene variants in the general population, as well as uncertainties with incomplete penetrance and variable expressivity, and challenges in variant calling. $\underline{8} \underline{9}$ These factors complicate the applicability and clinical implications of a given gene variant. Understanding the frequency and penetrance of DCM-associated gene variants in the general population is critical to patient and family counseling and clinical decisionmaking in those with incidental findings. However, to date, the prevalence and penetrance of DCMassociated pathogenic variants in the general population remain insufficiently investigated.

Using the UK Biobank, we aimed to: 1) determine the frequency of putative pathogenic variants in the ClinGen DCM Gene Curation Expert Panel (GCEP)-asserted genes; $\underline{4}$ 2) determine clinical DCM penetrance based on electronic health records; 3) identify patients with subclinical DCM or DCM features using advanced, quantitative 12-lead electrocardiographic (ECG) and cardiovascular magnetic resonance (CMR) imaging data; and 4) assess the impact of putative pathogenic variants in DCM-associated genes on patient outcomes. This study provides a large-scale genotype-phenotype correlation for DCM genes in the middle to older aged adult population and in a subset of participants with clinically diagnosed DCM, with a focus on the expression of clinical and subclinical phenotype, and considering structural and arrhythmic features of DCM. 


\section{METHODS}

\subsection{Study population}

The UK Biobank study is a prospective study of 502,493 UK residents aged between 40-69 years at enrollment, who were recruited at 22 assessment centers across the United Kingdom.10 Participants attended a center visit undergoing deep phenotyping, including anthropometric measurements, extensive health and lifestyle questionnaires and biological samples. This provided information on baseline characteristics and self-reported medical conditions. Additional links to primary care records and external hospital data records provided, in the form of ICD-10 diagnostic codes and OPCS-4 operation codes, data from hospital admissions. The survival status was updated until January 2018, generating long-term follow-up data. A subset of participants in the UK Biobank have undergone a selection of whole exome sequencing (WES), CMR and 12-lead ECG recordings; this subset comprised the cohort of this study. The UK Biobank received approval from the North West Multi-Centre Research Ethics Committee.

\subsection{Gene-first approach to identify the study population}

Amongst UK Biobank participants, 200,000 underwent WES as previously described.11 For this study, we used a panel of 44 genes recently asserted to be implicated in DCM by the ClinGen DCM GCEP. $\underline{4}$ This panel includes 11 genes with definite evidence (BAG3, DES, FLNC, LMNA, MYH7, PLN, RBM20, SCN5A, TNNC1, TNNT2, TTN), one with strong evidence (DSP), seven with moderate evidence (ACTC1, ACTN2, JPH2, NEXN, TNNI3, TPM1, VCL) and 25 with limited evidence for causality in monogenic DCM (ABCC9, ANKRD1, CSRP3, CTF1, DSG2, DTNA, EYA4, GATAD1, ILK, LAMA4, LDB3, MYBPC3, MYH6, MYL2, MYPN, NEBL, NKX2-5, OBSCN, PLEKHM2, PRDM16, PSEN2, SGCD, TBX20, TCAP, $T N N I 3 K) . \underline{4}$ We used three variant filtering strategies (one primary and two secondary) to classify variants. For all strategies, we restricted the analysis to only high quality (read depth $\geq 10$, call quality $\geq 20$, and genotype quality $\geq 20$ ) and rare variants (minor allele frequency $\leq 0.001$ in both gnomAD 12 and the UK Biobank exome dataset). A separate analysis was performed for the American College of Medical Genetics and Genomics (ACMG) clinically actionable DCM genes (TNNT2, LMNA, FLNC, and TTN). 13

In the first filtering strategy ("missense pLOF FAF", main strategy), we used ANNOVAR 14 annotations and REVEL scores (a method for predicting deleterious missense variants $\underline{15}$ ) to determine a set of putative pathogenic variants (as used elsewhere16 17). Variants with ANNOVAR annotations of either frameshift insertions/deletions, gain/loss of stop codon, or disruption of canonical splice site dinucleotides were classified as predicted loss-of-function variant (pLOF). Missense variants were determined as predicted pathogenic if the annotated REVEL score was $\geq 0.65 .16$ For TTN, only radical variants (i.e., nonsense, frameshift, and splice-site variants) were considered. We applied a further filtering allele frequency (FAF), removing all variants with a FAF of $8.4 \times 10^{-5}$ or greater in gnomAD and/or UK 
medRxiv preprint doi: https://doi.org/10.1101/2021.11.22.21266651; this version posted November $24,2021$. The copyright holder for this preprint (which was not certified by peer review) is the author/funder, who has granted medRxiv a license to display the preprint in perpetuity.

It is made available under a CC-BY-NC-ND 4.0 International license .

Biobank $\underline{18}$ to produce our final set of variants. Due to the population prevalence of DCM, variants that occur more frequently than this are unlikely to be causative variants under a monogenic Mendelian model. This frequency threshold for DCM and other inherited cardiac conditions has been previously defined. 18

Two secondary variant filtering strategies were performed ("InterVar FAF" and "InterVar FAF ClinVar"). Criteria used for these variant filtering strategies are provided in the Supplementary Methods.

\subsection{Quality control of variant filtering strategy based on clinical DCM population}

Prior to applying our genetic testing approach to the study population, we performed a quality-control analysis of the filtering and variant calling strategies on individuals with the clinical diagnosis of DCM WES (see subsection 3.1 in the Results).

\subsection{ECG analysis}

All individuals who underwent CMR also underwent 12-ECG recording. Briefly, 10 electrodes were placed in standard position, recorded at a frequency of $500 \mathrm{~Hz}$ for 10 seconds (Cardiosoft v6.51 GE, Wauwatosa, WI, USA) and stored in XML file format. These files were downloaded and reprocessed using GE MUSE v9.0 SP4, Marquette 12 SL.19 Unusable ECG tracings were manually confirmed and removed. Of the remaining, 100 were randomly selected and underwent manual review by a boardcertified cardiologist masked to the clinical diagnoses, CMR or genetic status. These were then classified into brady- and tachyarrhythmias, conduction system disease using established criteria (see Table S1 for details). $\underline{20}$

\subsection{CMR analysis}

The UK Biobank CMR protocol has been described previously.21 In brief, all CMR scans were acquired on a wide-bore 1.5 Tesla scanner (MAGNETOM Aera, Syngo Platform VD13A, Siemens Healthcare, Erlangen, Germany). The practical and ethical considerations posed by the large scale and observational nature of the UKB preclude the use of contrast or stress agents. The protocol includes bright blood anatomic assessment (sagittal, coronal, and axial), balanced and steady-state free precession (SSFP) sequences, left and right ventricular SSFP cine images (long and short axes), myocardial tagging (three short-axis slices), native T1 mapping, aortic flow, and imaging of the thoracic aorta. Typical parameters were: TR/TE $\square=\square 2.6 / 1.1 \mathrm{~ms}$, flip angle $80^{\circ}$, GRAPPA factor 2 , voxel size $1.8 \square \times \square 1.8 \square \times \square 8 \mathrm{~mm}^{3}(6 \mathrm{~mm}$ for long axis). The actual temporal resolution of $32 \mathrm{~ms}$ was interpolated to 50 phases per cardiac cycle ( $20 \mathrm{~ms}$ ). Analysis was performed using Circle CVI post-processing software (Version 5.1.1, Circle Cardiovascular Imaging Inc., Calgary, Canada).22 Further details on phenotyping are given in the Supplementary Appendix. 


\subsection{Penetrance analysis}

We defined penetrant disease based on the DCM clinical spectrum as laid out in the 2016 ESC position statement on Dilated Cardiomyopathy. $\underline{23}$ Briefly, the spectrum includes DCM (LV dilation and hypokinesia), hypokinetic non-dilated cardiomyopathy (hypokinesia without LV dilatation), isolated LV dilation (LV dilation without hypokinesia) or arrhythmia and/or conduction disturbances. $\underline{23}$

Phenotypic definitions were based on a combination of clinical diagnosis (self-reported conditions and ICD-10 codes), procedures (self-reported and OPCS-4 codes), 12-ECGs, and cardiac CMR imaging (where available). A full list of phenotype definitions is shown in Table S1 and is adapted from definitions used elsewhere.24-26 The observed phenotype was graded to either 1) clinically diagnosed DCM; 2) early DCM features, including arrhythmia and/or cardiac conduction disease (CCD), isolated ventricular dilation, and subclinical DCM; or 3) phenotype-negative. Clinical DCM was defined by the presence of ICD-10 I42.0 whereas subclinical DCM was defined by the fulfillment of the CMR criteria for DCM in the absence of a clinical history of DCM. In the classification of phenotype, the prioritization of phenotype categories was as follows: clinical DCM > subclinical DCM > hypokinetic non-dilated cardiomyopathy > isolated ventricular dilatation > arrhythmia and/or CCD. For example, in the presence of ICD-10 code I42.0, the subject was considered to have clinical DCM regardless of other history features and ECG/CMR features. The diagnosis of hypokinetic non-dilated cardiomyopathy, isolated ventricular dilatation, and subclinical DCM derived from analysis of CMR data. The phenotype category 'arrhythmia and/or CCD' was defined as atrial fibrillation/flutter, bradyarrhythmia, CCD, pre-excitation syndrome, or ventricular arrhythmia.

The penetrance and outcome analyses was stratified based on gene-evidence clusters as defined by the ClinGen DCM Gene Curation Expert Panel. 4 Accordingly, genes were clustered in the following categories: definitive/strong, moderate, or limited evidence.

\subsection{Analysis of genetic yield in the clinical DCM population (Quality Control)}

Patients with a clinical DCM were identified from the UK Biobank population using ICD-10 code I42.0. Patients without clinically significant coronary artery disease were included; those with myocardial infarction or revascularization 26 , were excluded. Genetic yield was determined for ClinGen DCM GCEPasserted DCM associated genes and classified according to evidence category, $\underline{4}$ using the same filtering strategies as described above.

\subsection{Statistical analysis}

Statistical analysis was performed with R statistical computing and graphics software, Version 3.6.1, $\underline{27}$ 
medRxiv preprint doi: https://doi.org/10.1101/2021.11.22.21266651; this version posted November 24, 2021. The copyright holder for this preprint (which was not certified by peer review) is the author/funder, who has granted medRxiv a license to display the preprint in perpetuity.

It is made available under a CC-BY-NC-ND 4.0 International license .

using tidyverse $\underline{28}$ and tableone $\underline{29}$ packages. Continuous, normally distributed data is summarized as mean (standard deviation) and non-normally distributed data as median (interquartile range [IQR]). Continuous data were compared using a two-sample $t$-test and categorical data using a Chi-squared test to test for differences between genotype-positive and genotype-negative individuals. Details regarding outcome analysis are provided in the Supplementary Methods. 
medRxiv preprint doi: https://doi.org/10.1101/2021.11.22.21266651; this version posted November 24, 2021. The copyright holder for this preprint (which was not certified by peer review) is the author/funder, who has granted medRxiv a license to display the preprint in perpetuity.

It is made available under a CC-BY-NC-ND 4.0 International license .

\section{RESULTS}

\subsection{Quality control of variant filtering strategy based on clinical DCM population}

Among 502,462 UK Biobank participants, there were 1415 (0.28\%) individuals with the known clinical diagnosis of non-ischemic DCM (30.2\% female, mean age 59.8 \pm 7 years at enrolment). Table S2 shows the demographic characteristics of these patients. Among DCM patients, 340 (24\%) individuals underwent WES. Screening of genes ascertained to have at least limited evidence for causality in monogenic DCM revealed putative pathogenic variants in 55 (16\%) subjects (Figure S1). In accordance with previous observations, $\underline{30-32}$ truncating variants in the TTN gene were the most common ( $\mathrm{n}=17,31 \%$ of genotypepositive DCM cases, $5 \%$ of all genotyped DCM cases), followed by DSP variants $>1$ putative pathogenic variants ( $\mathrm{n}=5$ for each, $9.1 \%$ of genotype-positive DCM cases, $1.5 \%$ of all genotyped DCM cases). These observations validate our primary variant filtering strategy as one in line with that applied in clinical practice. Genetic test results in the clinical DCM subset using secondary variant filtering strategies are summarized in Figure S1.

\subsection{Study population}

Out of 502,462 participants in the UK Biobank (54.4\% female), 200,619 had undergone WES; 42,078 had 12-ECG, 39,616 had CMR. Given the staged approach to participant accrual, 18,665 participants had WES, 12-ECG, and CMR forming the study population $(52.7 \%$ female; average age: 55 years at recruitment and 64.4 years at last follow-up; Figure 1). Arrhythmia and/or cardiac conduction disease was present in 2,729 (14.6\%), isolated ventricular dilation in 522 (2.8\%), hypokinetic non-dilated cardiomyopathy in 645 (3.5\%), and clinical/subclinical DCM in 189 (1\%) subjects (Table 1).

\subsection{Prevalence of DCM-associated putative pathogenic variants in the UK Biobank}

Among 18,665 individuals, 1,463 (7.8\%) were found to host at least one putative pathogenic variant in DCM-associated genes using the primary variant filtering strategy (igure 2). Putative pathogenic variants were found in all 44 screened genes, and most frequently affected $O B S C N(\mathrm{n}=153,10.5 \%$ of all DCM genotype-positives), MYH6 ( $\mathrm{n}=149,10.2 \%), \operatorname{SCN} 5 A$ (n=140, 9.6\%), MYH7 (n=122, 8.3\%), FLNC (n=121, 8.3\%), MYBPC3 $(\mathrm{n}=46,3.1 \%)$, and TTN genes $(\mathrm{n}=44,3 \%)$. There were 30 individuals with LMNA variants (2\%). Sixty-five individuals (4.4\%) carried two or more putative pathogenic variants in the same or different genes. The prevalence of putative pathogenic variants according to secondary filtering strategies are provided in Supplementary Material (Figure S2).

3.4. Clinical disease penetrance of DCM-associated putative pathogenic variants in the UK Biobank 
medRxiv preprint doi: https://doi.org/10.1101/2021.11.22.21266651; this version posted November $24,2021$. The copyright holder for this preprint (which was not certified by peer review) is the author/funder, who has granted medRxiv a license to display the preprint in perpetuity.

It is made available under a CC-BY-NC-ND 4.0 International license .

Among 1,463 putative pathogenic variant carriers, five individuals had a clinical diagnosis of DCM; 14 additional individuals diagnosed with DCM did not host any putative pathogenic variants (Table 2). Those with putative pathogenic variants more frequently had heart failure ( 2.1 vs. $1.2 \%, \mathrm{p}=0.01)$, but the risk of developing heart failure was not different between groups (HR 1.46 [CI 0.96 - 2.24]). Patients with putative pathogenic variants did not show any difference in LVEF, LVESV, LVEDV, age at recruitment, death at follow-up, or age at death, in comparison to those without (Table 3). The comparison of demographic and clinical characteristics of participants with and without putative pathogenic variants according to secondary variant filtering strategies is provided in Table $\mathbf{S 3}$.

\subsection{Subclinical DCM and early DCM features in individuals with putative pathogenic variants}

When assessed based on the CMR data, 24 (1.6\%) additional individuals with putative pathogenic variants met the diagnostic criteria for DCM (subclinical DCM). There were no differences in the frequency of early DCM features between genotype-positive and genotype-negative groups.

\subsection{Combined clinical and subclinical penetrance for DCM and early DCM-associated features} Overall, 346 (23.7\%) individuals with putative pathogenic variants had DCM or showed early phenotypic features that may in part be attributed to DCM, most frequently arrhythmia and/or cardiac conduction disease $(n=223,64 \%)$. The overall penetrance of putative pathogenic variants combined for subclinical/clinical DCM and early DCM features, varied between $0 \%$ and $66.7 \%$ in those with single putative pathogenic gene variants and between $0 \%$ and $100 \%$ in those with two or more putative pathogenic variants. Overall, individuals with putative pathogenic variants more frequently developed a clinical or subclinical DCM phenotype, as compared with those without putative pathogenic variants (2\% vs $1 \%, \mathrm{p}=0.00073$, Table 3 ).

\subsection{Penetrance analysis based on gene-evidence category}

A gene-evidence cluster-based analysis revealed slightly higher frequency of clinical DCM in participants with putative pathogenic variants in definitive/strong evidence genes, as compared to those with variants in moderate/limited evidence genes. However, combined clinical and subclinical phenotype was not statistically different between groups stratified based on gene-evidence category (Table 4).

\subsection{Prevalence of DCM-associated putative pathogenic gene variants using primary and secondary variant calling strategies}

One or more putative pathogenic variant(s) in DCM-associated genes were identified in 1463 (7.8\%) with the "missense pLOF FAF" variant calling strategy, in 154 (0.8\%) using the "InterVar FAF" strategy and in $212(1.1 \%)$ using the "InterVar FAF ClinVar" strategy (Table S4). The rate of diagnosis of clinical 
DCM varied between 0.3 and 1.4\%. Early clinical features DCM (5.7-7.6\%) were present in <8\% of individuals carrying putative pathogenic variants; an additional 16.89-17.6\% had a subclinical phenotype on ECG and/or CMR using different variant calling strategies. With a combined clinical/subclinical prevalence of $12.3-15.6 \%$, arrhythmias and/or conduction disease were the most common early DCM features, followed by hypokinetic non-dilated cardiomyopathy, observed in 4.0-7.8\%. The combined clinical/subclinical penetrance was $\leq 30 \%$ for all variant filtering strategies (Table 2 and Table S4).

\subsection{Gene-based analysis of penetrance and clinical phenotype}

Overall, putative pathogenic variants were found in all screened 44 genes by the missense pLOF FAF strategy, and in a lower number of genes when using the more strict secondary strategies. The genespecific penetrance ranged from 0 to $66.7 \%$ (Figure 2). A subanalysis for genes TNNT2, LMNA, FLNC, and TTN, which are listed in the ACMG clinically actionable gene list, revealed DCM or early DCM features in respectively $10.5 \%, 26.7 \%, 22.3 \%$, and $45.4 \%$ of cases, indicating higher penetrance than in the overall putative pathogenic population. Gene-based analysis of penetrance for additional filtering strategies is provided in Figure S2 and Tables S5-S7.

\subsection{Impact of DCM-associated putative pathogenic variants on clinical outcomes}

In order to assess the impact of DCM-associated putative pathogenic variants on the clinical outcome, an event-free survival analysis was performed for genotype-positive versus genotype negative patients for each of the three variant filtering strategies. Event-free survival was defined as survival without developing one of heart failure, stroke, arrhythmia, required CIED, or death. There was no statistical difference in the survival between individuals with and without putative pathogenic variants (HR 1.06 [95\%CI 0.87 - 1.29] for the primary strategy; Figure S3). Additional analysis regarding prevalence and incidence of DCM and potentially DCM-associated clinical features in genotype-positive and genotypenegative groups are provided in Tables S8-S9. 
medRxiv preprint doi: https://doi.org/10.1101/2021.11.22.21266651; this version posted November $24,2021$. The copyright holder for this preprint (which was not certified by peer review) is the author/funder, who has granted medRxiv a license to display the preprint in perpetuity.

It is made available under a CC-BY-NC-ND 4.0 International license .

\section{DISCUSSION}

Using the UK Biobank WES data, we analyzed the prevalence and penetrance of DCM-associated gene variants in a cohort of over 18,000 individuals with 12-lead ECG and CMR. This is the first study providing insights into the clinical and subclinical penetrance of DCM-associated gene variants in a large population-scale dataset and has several important findings with direct clinical implications. First, the UK Biobank population of mainly middle-aged adults has a prevalence of non-ischemic DCM of 1:355 $(0.28 \%)$. Second, the variant filtering strategy used for those with a clinical diagnosis of DCM provided a yield of $16 \%$. Third, using the same strategy and a genotype-first approach identified 1,463 (7.8\%) individuals with putative pathogenic DCM gene variants. Fourth, clinical/subclinical disease penetrance was highly variable, ranging from 0 to $66.7 \%$ between genes. Fifth, among individuals with putative pathogenic DCM variants, subclinical DCM and early DCM features, detected by 12-ECG and/or CMR, were five times more common than clinically manifest DCM (21.6\% vs. 3.8\%; p<0.00001) (Figure 3 ). Finally, participants with putative pathogenic variants in definitive/strong DCM genes appeared to have slightly higher rate of clinical DCM, than those with variants in lower evidence genes, but combined clinical and subclinical phenotype was not statistically different between groups stratified based on geneevidence categories.

Our analysis indicates a DCM prevalence of 1:355 in the UK Biobank population, with over 3.3:1 male predominance, in line with previous population-based epidemiological studies of non-ischemic DCM. 33 , 34 Studies reporting a prevalence of 1 in 250 have, perhaps, included all etiologies of a morphological DCM phenotype. Among individuals with putative pathogenic variants in the screened DCM-associated genes, only $0.3 \%$ had a clinically diagnosed DCM, but an additional 1.6\% (5-fold increase) were found to meet the CMR criteria for DCM, indicating that most DCM cases in the general adult population go unnoticed for many years. Interestingly, the 12-lead ECG and CMR screening in those with putative pathogenic variants identified $16.2 \%$ of individuals with subclinical early features of DCM, such as cardiac arrhythmias, isolated ventricular dilation, and hypokinetic non-dilated DCM. In fact, the population with early DCM features was 11-fold larger than those with clinical and subclinical DCM combined ( $21.7 \%$ vs. $2 \%$ ), demonstrating the wide variability of phenotypic expression in individuals with putative pathogenic variants in DCM genes. Arrhythmias and CCD were the most common early manifestation of putative pathogenic variants implicated in DCM, mostly occurring prior to the development of structural/functional abnormalities. These findings are in line with observations in the large and well-phenotyped Geisinger database, showing very low penetrance of arrhythmogenic right ventricular cardiomyopathy-associated $P K P 2$ variants in the middle-aged population. 35

An unsolved challenge in clinical genetics is that the principles applied to variant calling are probabilistic. While the 2015 ACMG guidelines integrate a robust data scheme to classify gene 
variants, $\underline{36}$ applying these criteria to biobank studies is challenging because expert-curator input is often necessary to assess variant pathogenicity and gene-disease association. Here, we applied three special variant calling models developed for this study to all genes, except for TTN, where we only considered radical variants as putative pathogenic variants. The two secondary filtering strategies we used can be considered more stringent than the primary strategy; these yielded a lower frequency of variants in the studied population with a similar low penetrance, indicating that the true DCM penetrance is very low regardless of variant calling strategy. On the other hand, many genes, such as SCN5A, DSP, MYH7, DES, and others, show broad pleiotropy and variability of phenotypic expression, making the definition of positive phenotype in large datasets rather complicated. In order to extend the breadth of recognizable phenotypes we included early features of DCM. However, it is possible that the individuals with putative pathogenic variants in DCM genes, who showed no DCM features, manifest other cardiomyopathy phenotypes, or in the case of $S C N 5 A$, primary arrhythmia syndromes. $\underline{37}$

Of the genes included in the ClinGen DCM panel used in this study to define a DCM-relevant gene panel, TNNT2, LMNA, FLNC, and TTN are among the 59 genes identified as medically actionable by the ACMG, $\underline{13}$ for which clinical management guidelines have been established. In the UK Biobank subcohort, individuals with putative pathogenic variants in the TNNT2, LMNA, FLNC and TTN genes showed signs of DCM or early DCM features in respectively $10.5 \%, 26.7 \%, 22.3 \%$, and $45.4 \%$ of cases. Indeed, this is significantly higher penetrance than that seen in the overall DCM gene panel.

Although individuals with putative pathogenic variants in DCM genes had a markedly higher observed frequency of clinical/subclinical DCM and two-fold higher frequency of heart failure, our analysis reflects low penetrance of DCM-associated putative pathogenic variants in a middle to older aged individuals, indicating that most of these individuals are unlikely to develop disease. The presence of a putative pathogenic variant in the DCM-associated genes was not associated with a higher risk of heart failure or worse outcome, similar to the findings of Carruth et al. for pathogenic alleles in the PKP2 gene. 35 It should be noted that monogenic disease expressivity and penetrance, particularly in DCM, is dependent on genomic context, as indicated by family history or the effect of polygenic risk, $\underline{38} \underline{39}$ as well as the environment (e.g. alcohol and pregnancy in $T T N t v$-mediated DCM, inflammation in DSP-mediated cardiomyopathy). $40-43$ Future studies investigating population penetrance of DCM should consider disease modifiers and approach to DCM as a multifactorial trait highly influenced by environmental and genetic modifiers.

A population-based 'genotype first' screening strategy must fulfill certain criteria in order to be cost-effective.44 First, the condition should be a sufficient health problem, which DCM is. Second, the natural history should be understood. In DCM, this is in part understood, but as multimodality imaging and physician awareness improve, we have learned that the natural history can be quite different for this genetically heterogeneous group. Third, there should be a recognizable latent or early symptomatic stage, 
which for heart failure, isolated ventricular dilation and hypokinetic non-dilated cardiomyopathy is applicable to DCM. However, for those in whom the sentinel event is sudden death, this is not fulfilled. Fourth, there should be a suitable test or examination, which is fulfilled by echocardiography and CMR. Fifth, screening should be acceptable to the population, and, in general, cardiovascular diseases are. Sixth and seventh, there should be an agreed policy on whom to treat and expected treatment, both of which are well satisfied regarding established heart failure syndrome and arrhythmia, but not agreed on asymptomatic mild or subclinical disease. Eighth, facilities for diagnosis and treatment should be available, which has been achieved throughout most of the developed world, though disparities persist and remain lacking in the developing nations. 45 Ninth, the cost of case finding, diagnosis, and treatment, should be economically balanced, which with clinical diagnosis is justified, but for genetics, it is difficult to justify given upfront costs and the low signal-to-noise ratio. This may be improved with a targeted panel of very high-risk genes and higher penetrance. In our study, only TTNtv would meet this criteria, whereas genes considered as high-risk in consensus statements and guidelines, such as DSP, LMNA, RBM20, SCN5A, FLNC, and PLN, $\underline{46}$ had a low frequency of putative pathogenic variants and low penetrance. Based on current data, a genotype-first screening strategy in DCM would be difficult to justify due to high cost and low penetrance. However, this should be interpreted in the context of this dataset being a relatively healthy and older population, where high-risk individuals may have succumbed to sudden death or not enrolled. Lastly, case finding should be a continuous process, and applying this to clinical screening for presentations of DCM may be better achieved through phenotype screening tools such as artificial intelligence-enabled ECG. $\underline{47}$ Years later, this methodology may be a more cost-effective approach than a genetic screening tool and then continuous clinical phenotyping, which are currently prohibitively expensive.

\section{Strengths and Limitations}

Our study has a number of strengths. First, we used a robust methodology with one primary and two secondary variant calling strategies, which all confirmed the low yield of clinical and subclinical DCM in putative pathogenic variant carriers. Second, in order to include early DCM features as defined by Pinto et al.23, as well as those with subclinical DCM, we analyzed electronic health records, 12-lead ECG and CMR data to enable the deeper phenotyping of individuals. Of note, this is the first study to report detailed high throughput computer interpretation, with manual validation, of 12-lead ECGs from the UK Biobank population. Third, our study included a cohort of over 18,000 individuals who underwent CMR according to a standardized protocol.

The study results should be viewed in light of several limitations. First, some DCM genes show significant pleiotropy with the development of distinct phenotypes. We did not consider phenotypic features other than DCM or early DCM features. This may have resulted in underestimation of the clinical 
penetrance of these genes when it relates to other phenotypes. Second, the UK Biobank population may reflect volunteer bias and survivor bias with a sample of healthier individuals than the general UK population, $\underline{48}$ and thus may show lower frequency of putative pathogenic variants and lower penetrance. Third, the ethnicity is mainly White British individuals, making generalizability to other ethnicities challenging, particularly in a disease with known differences in genetic etiology in different races. $\underline{49}, \underline{50}$ Fourth, although 200,000 WES data are available, only 18,000 had both 12-lead ECG and CMR available (which were usable); with the staged approach, and impacts of the pandemic, the goals of 500,000 WES and 100,000 with 12-lead ECG and CMR are unlikely to be achieved on time. A larger sample of 100,000 and with longer follow-up may show higher penetrance, given the age of onset of DCM is also variable. The UK Biobank does not include recruits aged less than 40 years, which may underestimate prevalence, and exclude high-risk DCM patients who succumb to sudden death events. Detection of late gadolinium enhancement is not part of UK Biobank CMR protocol; right ventricular phenotypic expression was not evaluated for this study.

\section{CONCLUSIONS}

Over $90 \%$ of middle and older aged adults with putative pathogenic variants in DCM-associated genes did not have a history of DCM or of early DCM features. Nearly one-sixth of putative pathogenic variant carriers exhibited a subclinical phenotype on ECG and/or CMR, most commonly manifesting with arrhythmias in the absence of substantial ventricular dysfunction. Given the difficulties in variant pathogenicity adjudication, low disease penetrance and uncertainties in clinical actionability, applying a gene-first approach to DCM for clinical and investigative decision making might currently be challenging for a broad gene panel, but might be useful for clinically actionable genes, which show a relatively higher penetrance. 
medRxiv preprint doi: https://doi.org/10.1101/2021.11.22.21266651; this version posted November $24,2021$. The copyright holder for this preprint (which was not certified by peer review) is the author/funder, who has granted medRxiv a license to display the preprint in perpetuity.

It is made available under a CC-BY-NC-ND 4.0 International license .

\section{Acknowledgments}

This study was conducted using the UK Biobank resource under access application 48286.

We would like to thank all the participants, staff involved with planning, collection and analysis, including core lab analysis of the CMR imaging data.

\section{Sources of Funding}

APL is supported by the American Academy of Pediatrics, Children's Cardiomyopathy Foundation, and the Derfner Foundation. AML reports funding from UKRI London Medical Imaging \& Artificial Intelligence Centre for Value Based Healthcare and SmartHeart" EPSRC program grant (EP/P001009/1). LRL is funded by MRC UK Clinical Academic Research Partnership award (MR/T005181/1). CS is the recipient of a National Health and Medical Research Council (NHMRC) Practitioner Fellowship (\#1154992). SEP acknowledge the British Heart Foundation for funding the manual analysis to create a cardiovascular magnetic resonance imaging reference standard for the UK Biobank imaging resource in 5000 CMR scans (www.bhf.org.uk; PG/14/89/31194). NA recognises the National Institute for Health Research (NIHR) Integrated Academic Training programme, which supports his Academic Clinical Lectureship post. SEP and PBM acknowledge support from the National Institute for Health Research (NIHR) Biomedical Research Centre at Barts. SEP acknowledges support from and from the "SmartHeart" EPSRC programme grant (www.nihr.ac.uk; EP/P001009/1). This project was enabled through access to the MRC eMedLab Medical Bioinformatics infrastructure, supported by the Medical Research Council (www.mrc.ac.uk; MR/L016311/1). The funders provided support in the form of salaries for authors as detailed above, but did not have any additional role in the study design, data collection and analysis, decision to publish, or preparation of the manuscript.

\section{Disclosures}

Dr. Lopes serves in the advisory board of BMS. Dr. Owens provided consulting to BMS and Cytokinetics. Dr. Petersen provided consultancy to and is shareholder of Circle Cardiovascular Imaging Inc., Calgary, Alberta, Canada. The other authors report that they have no relevant conflicts of interest to disclose. 


\section{REFERENCES}

1. Schultheiss HP, Fairweather D, Caforio ALP, Escher F, Hershberger RE, Lipshultz SE, Liu PP, Matsumori A, Mazzanti A, McMurray J, et al. Dilated cardiomyopathy. Nat Rev Dis Primers. 2019;5:32.

2. Patel V, Asatryan B, Siripanthong B, Munroe PB, Tiku-Owens A, Lopes LR, Khanji MY, Protonotarios A, Santangeli P, Muser D, et al. State of the Art Review on Genetics and Precision Medicine in Arrhythmogenic Cardiomyopathy. Int J Mol Sci. 2020;21.

3. McNally EM and Mestroni L. Dilated Cardiomyopathy: Genetic Determinants and Mechanisms. Circ Res. 2017;121:731-748.

4. Jordan E, Peterson L, Ai T, Asatryan B, Bronicki L, Brown E, Celeghin R, Edwards M, Fan J, Ingles $\mathbf{J}$, et al. Evidence-Based Assessment of Genes in Dilated Cardiomyopathy. Circulation. 2021;144:7-19.

5. Asatryan B and Medeiros-Domingo A. Translating emerging molecular genetic insights into clinical practice in inherited cardiomyopathies. J Mol Med (Berl). 2018;96:993-1024.

6. Hershberger RE, Cowan J, Jordan E and Kinnamon DD. The Complex and Diverse Genetic Architecture of Dilated Cardiomyopathy. Circ Res. 2021;128:1514-1532.

7. Ahmad F, McNally EM, Ackerman MJ, Baty LC, Day SM, Kullo IJ, Madueme PC, Maron MS, Martinez MW, Salberg L, et al. Establishment of Specialized Clinical Cardiovascular Genetics Programs: Recognizing the Need and Meeting Standards: A Scientific Statement From the American Heart Association. Circ Genom Precis Med. 2019;12:e000054.

8. Marian AJ, Asatryan B and Wehrens XHT. Genetic basis and molecular biology of cardiac arrhythmias in cardiomyopathies. Cardiovasc Res. 2020;116:1600-1619.

9. Hershberger RE, Hedges DJ and Morales A. Dilated cardiomyopathy: the complexity of a diverse genetic architecture. Nat Rev Cardiol. 2013;10:531-547.

10. Sudlow C, Gallacher J, Allen N, Beral V, Burton P, Danesh J, Downey P, Elliott P, Green J, Landray M, et al. UK biobank: an open access resource for identifying the causes of a wide range of complex diseases of middle and old age. PLoS Med. 2015;12:e1001779.

11. Szustakowski JD, Balasubramanian S, Sasson A, Khalid S, Bronson PG, Kvikstad E, Wong E, Liu D, Davis JW, Haefliger C, et al. Advancing Human Genetics Research and Drug Discovery through Exome Sequencing of the UK Biobank. medRxiv. 2020:2020.2011.2002.20222232.

12. Karczewski KJ, Francioli LC, Tiao G, Cummings BB, Alfoldi J, Wang Q, Collins RL, Laricchia KM, Ganna A, Birnbaum DP, et al. The mutational constraint spectrum quantified from variation in 141,456 humans. Nature. 2020;581:434-443.

13. Miller DT, Lee K, Chung WK, Gordon AS, Herman GE, Klein TE, Stewart DR, Amendola LM, Adelman K, Bale SJ, et al. ACMG SF v3.0 list for reporting of secondary findings in clinical exome and 
genome sequencing: a policy statement of the American College of Medical Genetics and Genomics (ACMG). Genet Med. 2021;23:1381-1390.

14. Wang K, Li M and Hakonarson H. ANNOVAR: functional annotation of genetic variants from high-throughput sequencing data. Nucleic Acids Res. 2010;38:e164.

15. Ioannidis NM, Rothstein JH, Pejaver V, Middha S, McDonnell SK, Baheti S, Musolf A, Li Q, Holzinger E, Karyadi D, et al. REVEL: An Ensemble Method for Predicting the Pathogenicity of Rare Missense Variants. Am J Hum Genet. 2016;99:877-885.

16. Park J, Levin MG, Haggerty CM, Hartzel DN, Judy R, Kember RL, Reza N, Regeneron Genetics $\mathrm{C}$, Ritchie MD, Owens AT, et al. A genome-first approach to aggregating rare genetic variants in LMNA for association with electronic health record phenotypes. Genet Med. 2020;22:102-111.

17. Park J, Lucas AM, Zhang X, Chaudhary K, Cho JH, Nadkarni G, Dobbyn A, Chittoor G, Josyula NS, Katz N, et al. Exome-wide evaluation of rare coding variants using electronic health records identifies new gene-phenotype associations. Nat Med. 2021;27:66-72.

18. Whiffin N, Walsh R, Govind R, Edwards M, Ahmad M, Zhang X, Tayal U, Buchan R, Midwinter W, Wilk AE, et al. CardioClassifier: disease- and gene-specific computational decision support for clinical genome interpretation. Genet Med. 2018;20:1246-1254.

19. Marquette ${ }^{\mathrm{TM}}$ 12SL ${ }^{\mathrm{TM}}$ ECG Analysis Program Physician's Guide 2036070-006 Revision C, 2010, 2012 General Electric Company.

20. Mason JW, Hancock EW, Gettes LS, Bailey JJ, Childers R, Deal BJ, Josephson M, Kligfield P, Kors JA, Macfarlane P, et al. Recommendations for the standardization and interpretation of the electrocardiogram: part II: electrocardiography diagnostic statement list a scientific statement from the American Heart Association Electrocardiography and Arrhythmias Committee, Council on Clinical Cardiology; the American College of Cardiology Foundation; and the Heart Rhythm Society Endorsed by the International Society for Computerized Electrocardiology. J Am Coll Cardiol. 2007;49:1128-1135.

21. Petersen SE, Matthews PM, Francis JM, Robson MD, Zemrak F, Boubertakh R, Young AA, Hudson S, Weale P, Garratt S, et al. UK Biobank's cardiovascular magnetic resonance protocol. $J$ Cardiovasc Magn Reson. 2016;18:8.

22. Suinesiaputra A, Sanghvi MM, Aung N, Paiva JM, Zemrak F, Fung K, Lukaschuk E, Lee AM, Carapella V, Kim YJ, et al. Fully-automated left ventricular mass and volume MRI analysis in the UK Biobank population cohort: evaluation of initial results. Int J Cardiovasc Imaging. 2018;34:281-291.

23. Pinto YM, Elliott PM, Arbustini E, Adler Y, Anastasakis A, Bohm M, Duboc D, Gimeno J, de Groote P, Imazio M, et al. Proposal for a revised definition of dilated cardiomyopathy, hypokinetic nondilated cardiomyopathy, and its implications for clinical practice: a position statement of the ESC working group on myocardial and pericardial diseases. Eur Heart J. 2016;37:1850-1858. 
24. Aragam KG, Chaffin M, Levinson RT, McDermott G, Choi SH, Shoemaker MB, Haas ME, Weng LC, Lindsay ME, Smith JG, et al. Phenotypic Refinement of Heart Failure in a National Biobank Facilitates Genetic Discovery. Circulation. 2018;139:489-501.

25. Khurshid S, Choi SH, Weng LC, Wang EY, Trinquart L, Benjamin EJ, Ellinor PT and Lubitz SA. Frequency of Cardiac Rhythm Abnormalities in a Half Million Adults. Circ Arrhythm Electrophysiol. 2018;11:e06273.

26. Khera AV, Chaffin M, Aragam KG, Haas ME, Roselli C, Choi SH, Natarajan P, Lander ES, Lubitz SA, Ellinor PT, et al. Genome-wide polygenic scores for common diseases identify individuals with risk equivalent to monogenic mutations. Nat Genet. 2018;50:1219-1224.

27. R: A language and environment for statistical computing. [computer program]. Version 3.6.1: $\mathrm{R}$ Foundation for Statistical Computing; 2019.

28. Wickham H, Averick M, Bryan J, Chang W, McGowan L, François R, Grolemund G, Hayes A, Henry L, Hester J, et al. Welcome to the Tidyverse. Journal of Open Source Software. 2019;4.

29. tableone: Create 'Table 1' to Describe Baseline Characteristics with or without Propensity Score Weights [computer program]. Version R package version 0.12.0; 2020.

30. Herman DS, Lam L, Taylor MR, Wang L, Teekakirikul P, Christodoulou D, Conner L, DePalma SR, McDonough B, Sparks E, et al. Truncations of titin causing dilated cardiomyopathy. $N$ Engl J Med. 2012;366:619-628.

31. Tabish AM, Azzimato V, Alexiadis A, Buyandelger B and Knoll R. Genetic epidemiology of titin-truncating variants in the etiology of dilated cardiomyopathy. Biophys Rev. 2017;9:207-223.

32. Esslinger U, Garnier S, Korniat A, Proust C, Kararigas G, Muller-Nurasyid M, Empana JP, Morley MP, Perret C, Stark K, et al. Exome-wide association study reveals novel susceptibility genes to sporadic dilated cardiomyopathy. PLoS One. 2017;12:e0172995.

33. Codd MB, Sugrue DD, Gersh BJ and Melton LJ, 3rd. Epidemiology of idiopathic dilated and hypertrophic cardiomyopathy. A population-based study in Olmsted County, Minnesota, 1975-1984. Circulation. 1989;80:564-572.

34. Fairweather D, Cooper LT, Jr. and Blauwet LA. Sex and gender differences in myocarditis and dilated cardiomyopathy. Curr Probl Cardiol. 2013;38:7-46.

35. Carruth ED, Young W, Beer D, James CA, Calkins H, Jing L, Raghunath S, Hartzel DN, Leader JB, Kirchner HL, et al. Prevalence and Electronic Health Record-Based Phenotype of Loss-of-Function Genetic Variants in Arrhythmogenic Right Ventricular Cardiomyopathy-Associated Genes. Circ Genom Precis Med. 2019;12:e02579.

36. Richards S, Aziz N, Bale S, Bick D, Das S, Gastier-Foster J, Grody WW, Hegde M, Lyon E, Spector E, et al. Standards and guidelines for the interpretation of sequence variants: a joint consensus 
recommendation of the American College of Medical Genetics and Genomics and the Association for Molecular Pathology. Genet Med. 2015;17:405-424.

37. Asatryan B. Cardiac Sodium Channel Dysfunction and Dilated Cardiomyopathy: A Contemporary Reappraisal of Pathophysiological Concepts. J Clin Med. 2019;8.

38. Pirruccello JP, Bick A, Wang M, Chaffin M, Friedman S, Yao J, Guo X, Venkatesh BA, Taylor KD, Post WS, et al. Analysis of cardiac magnetic resonance imaging in 36,000 individuals yields genetic insights into dilated cardiomyopathy. Nat Commun. 2020;11:2254.

39. Haggerty CM, Damrauer SM, Levin MG, Birtwell D, Carey DJ, Golden AM, Hartzel DN, Hu Y, Judy R, Kelly MA, et al. Genomics-First Evaluation of Heart Disease Associated With Titin-Truncating Variants. Circulation. 2019;140:42-54.

40. Ware JS, Amor-Salamanca A, Tayal U, Govind R, Serrano I, Salazar-Mendiguchia J, GarciaPinilla JM, Pascual-Figal DA, Nunez J, Guzzo-Merello G, et al. Genetic Etiology for Alcohol-Induced Cardiac Toxicity. J Am Coll Cardiol. 2018;71:2293-2302.

41. Ware JS, Li J, Mazaika E, Yasso CM, DeSouza T, Cappola TP, Tsai EJ, Hilfiker-Kleiner D, Kamiya CA, Mazzarotto F, et al. Shared Genetic Predisposition in Peripartum and Dilated Cardiomyopathies. N Engl J Med. 2016;374:233-241.

42. Parikh VN. Promise and Peril of Population Genomics for the Development of Genome-First Approaches in Mendelian Cardiovascular Disease. Circ Genom Precis Med. 2021;14:e002964.

43. Asatryan B, Asimaki A, Landstrom AP, Khanji MY, Odening KE, Cooper LT, Marchlinski FE, Gelzer AR, Semsarian C, Reichlin T, et al. Inflammation and Immune Response in Arrhythmogenic Cardiomyopathy: State-of-the-Art Review. Circulation. 2021;144:1646-1655.

44. Wilson JMG, Jungner G and World Health Organization. Principles and practice of screening for disease / J. M. G. Wilson, G. Jungner. 1968.

45. Albert MA, Carnethon MR and Watson KE. Disparities in Cardiovascular Medicine. Circulation. 2021;143:2319-2320.

46. Towbin JA, McKenna WJ, Abrams DJ, Ackerman MJ, Calkins H, Darrieux FCC, Daubert JP, de Chillou C, DePasquale EC, Desai MY, et al. 2019 HRS expert consensus statement on evaluation, risk stratification, and management of arrhythmogenic cardiomyopathy. Heart Rhythm. 2019;16:e301-e372.

47. Attia ZI, Kapa S, Lopez-Jimenez F, McKie PM, Ladewig DJ, Satam G, Pellikka PA, EnriquezSarano M, Noseworthy PA, Munger TM, et al. Screening for cardiac contractile dysfunction using an artificial intelligence-enabled electrocardiogram. Nat Med. 2019;25:70-74.

48. Fry A, Littlejohns TJ, Sudlow C, Doherty N, Adamska L, Sprosen T, Collins R and Allen NE. Comparison of Sociodemographic and Health-Related Characteristics of UK Biobank Participants With Those of the General Population. Am J Epidemiol. 2017;186:1026-1034. 
medRxiv preprint doi: https://doi.org/10.1101/2021.11.22.21266651; this version posted November 24, 2021. The copyright holder for this preprint (which was not certified by peer review) is the author/funder, who has granted medRxiv a license to display the preprint in perpetuity.

It is made available under a CC-BY-NC-ND 4.0 International license .

49. Coughlin SS, Gottdiener JS, Baughman KL, Wasserman A, Marx ES, Tefft MC and Gersh BJ. Black-white differences in mortality in idiopathic dilated cardiomyopathy: the Washington, DC, dilated cardiomyopathy study. J Natl Med Assoc. 1994;86:583-591.

50. Myers VD, Gerhard GS, McNamara DM, Tomar D, Madesh M, Kaniper S, Ramsey FV, Fisher SG, Ingersoll RG, Kasch-Semenza L, et al. Association of Variants in BAG3 With Cardiomyopathy Outcomes in African American Individuals. JAMA Cardiol. 2018;3:929-938. 
Table 1. Demographic and clinical characteristics of the study population and of phenotypic subgroups.

\begin{tabular}{|c|c|c|c|c|c|c|}
\hline & Overall & $\begin{array}{l}\text { Phenotype } \\
\text { negative }\end{array}$ & $\begin{array}{l}\text { Arrhythmia } \\
\text { and/or CCD }\end{array}$ & $\begin{array}{c}\text { Isolated } \\
\text { ventricular } \\
\text { dilatation }\end{array}$ & $\begin{array}{l}\text { Hypokinetic non- } \\
\text { dilated } \\
\text { cardiomyopathy }\end{array}$ & DCM* \\
\hline $\mathbf{N}$ & 18665 & 14580 & 2729 & 522 & 645 & 189 \\
\hline Female, n (\%) & $9844(52.7)$ & $8345(57.2)$ & $938(34.4)$ & $281(53.8)$ & $195(30.2)$ & $85(45.0)$ \\
\hline Age at recruitment, yrs & $54.96(7.50)$ & $54.33(7.44)$ & $57.33(7.31)$ & $55.45(6.86)$ & $57.62(7.33)$ & $58.70(6.98)$ \\
\hline Age at last follow up, yrs & $64.38(7.47)$ & $63.78(7.41)$ & $66.72(7.32)$ & $64.82(6.81)$ & $66.96(7.25)$ & $67.99(6.96)$ \\
\hline $\begin{array}{l}\text { Systolic BP automated reading, } \\
\text { mmHg, mean (SD) }\end{array}$ & $136.75(18.66)$ & $135.84(18.37)$ & $140.70(19.33)$ & $140.12(19.75)$ & $136.80(18.27)$ & $140.23(20.10)$ \\
\hline $\begin{array}{l}\text { Diastolic BP automated reading, } \\
\text { mmHg, mean (SD) }\end{array}$ & $81.25(10.37)$ & $81.07(10.27)$ & $82.36(10.63)$ & $79.26(10.59)$ & $82.34(10.76)$ & $81.20(11.24)$ \\
\hline Body mass index, $\mathrm{kg} / \mathrm{m} 2$ & $26.51(4.16)$ & $26.43(4.13)$ & $26.89(4.21)$ & $25.90(4.20)$ & $27.06(4.30)$ & $27.09(4.39)$ \\
\hline Body surface area, m2 & $1.86(0.21)$ & $1.85(0.20)$ & $1.92(0.21)$ & $1.83(0.19)$ & $1.93(0.22)$ & $1.88(0.21)$ \\
\hline Creatinine, $(\mu \mathrm{mol} / \mathrm{L})$ & $72.12(14.09)$ & $71.34(13.88)$ & $75.68(14.67)$ & $70.44(13.25)$ & $76.46(14.30)$ & $71.92(13.00)$ \\
\hline Dead, n (\%) & $221(1.2)$ & $131(0.9)$ & $61(2.2)$ & $8(1.5)$ & $16(2.5)$ & $5(2.6)$ \\
\hline Age at death, yrs & $70.73(6.71)$ & $69.34(6.94)$ & $72.32(5.66)$ & $72.12(6.71)$ & $74.36(6.57)$ & $73.60(4.56)$ \\
\hline Coronary artery disease, $\mathbf{n}(\%)$ & $846(4.5)$ & $429(2.9)$ & $281(10.3)$ & $32(6.1)$ & $72(11.2)$ & $32(16.9)$ \\
\hline Heart failure, $\mathrm{n}(\%)$ & $240(1.3)$ & $60(0.4)$ & $96(3.5)$ & $20(3.8)$ & $40(6.2)$ & $24(12.7)$ \\
\hline Hypertension, n (\%) & $6028(32.3)$ & $4324(29.7)$ & $1192(43.7)$ & $168(32.2)$ & $254(39.4)$ & $90(47.6)$ \\
\hline Stroke, $\mathbf{n}(\%)$ & $330(1.8)$ & $213(1.5)$ & $88(3.2)$ & $13(2.5)$ & $13(2.0)$ & $3(1.6)$ \\
\hline Valvular heart disease, $\mathrm{n}(\%)$ & $527(2.8)$ & $229(1.6)$ & $197(7.2)$ & $43(8.2)$ & $45(7.0)$ & $13(6.9)$ \\
\hline Atrial fibrillation/flutter, $\mathbf{n}(\%)$ & $832(4.5)$ & $0(0.0)$ & $646(23.7)$ & $41(7.9)$ & $124(19.2)$ & $21(11.1)$ \\
\hline Bradyarrhythmia, n (\%) & $352(1.9)$ & $0(0.0)$ & $273(10.0)$ & $26(5.0)$ & $31(4.8)$ & $22(11.6)$ \\
\hline Cardiac conduction defect, $n(\%)$ & $2448(13.1)$ & $0(0.0)$ & $2141(78.5)$ & $125(23.9)$ & $123(19.1)$ & $59(31.2)$ \\
\hline Sick sinus syndrome, $\mathbf{n}(\%)$ & $19(0.1)$ & $0(0.0)$ & $13(0.5)$ & $5(1.0)$ & $1(0.2)$ & $0(0.0)$ \\
\hline CIED, n (\%) & $148(0.8)$ & $0(0.0)$ & $120(4.4)$ & $16(3.1)$ & $8(1.2)$ & $4(2.1)$ \\
\hline Pre-excitation syndrome, n (\%) & $35(0.2)$ & $0(0.0)$ & $32(1.2)$ & $1(0.2)$ & $2(0.3)$ & $0(0.0)$ \\
\hline Ventricular arrhythmia, n (\%) & $69(0.4)$ & $0(0.0)$ & $56(2.1)$ & $4(0.8)$ & $6(0.9)$ & $3(1.6)$ \\
\hline
\end{tabular}

$\mathrm{BP}=$ blood pressure; $\mathrm{DCM}=$ dilated cardiomyopathy; $\mathrm{CIED}=$ cardiac implantable electronic device (including single- and dual-chamber permanent

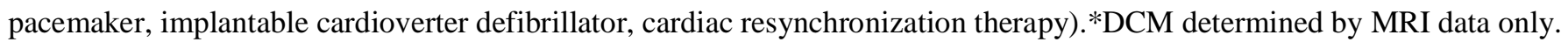


Table 2. Clinical and subclinical penetrance of DCM and DCM-associated clinical features in participants with putative pathogenic DCM variants.

\begin{tabular}{|c|c|c|c|c|c|c|c|}
\hline & \multirow[t]{3}{*}{ Filter } & \multirow[t]{3}{*}{ Overall } & \multirow{3}{*}{$\begin{array}{l}\text { Phenotype } \\
\text { negative }\end{array}$} & \multicolumn{4}{|c|}{ Phenotype positive } \\
\hline & & & & \multicolumn{3}{|c|}{ Early DCM features } & \multirow{2}{*}{ DCM } \\
\hline & & & & $\begin{array}{l}\text { Arrhythmia and/or } \\
\text { cardiac conduction } \\
\text { disease }\end{array}$ & $\begin{array}{l}\text { Isolated } \\
\text { ventricular } \\
\text { dilatation }\end{array}$ & $\begin{array}{c}\text { Hypokinetic } \\
\text { non-dilated } \\
\text { cardiomyopathy }\end{array}$ & \\
\hline $\begin{array}{c}\text { Clinical } \\
\text { phenotype }\end{array}$ & $\begin{array}{c}\text { Total } \\
\text { missense pLOF FAF }\end{array}$ & $\begin{array}{c}18665 \\
1463(7.8 \%)\end{array}$ & $\begin{array}{c}17545(94 \%) \\
1374(93.92 \%)\end{array}$ & $\begin{array}{l}1101(5.9 \%) \\
84(5.74 \%)\end{array}$ & $\begin{array}{l}\text { NA } \\
\text { NA }\end{array}$ & $\begin{array}{l}\text { NA } \\
\text { NA }\end{array}$ & $\begin{array}{l}19(0.1 \%) \\
5(0.34 \%)\end{array}$ \\
\hline $\begin{array}{c}\text { Subclinical } \\
\text { phenotype } \\
(\text { ECG + CMR) }\end{array}$ & $\begin{array}{c}\text { Total } \\
\text { missense pLOF FAF }\end{array}$ & $\begin{array}{c}18665 \\
1463(7.8 \%)\end{array}$ & $\begin{array}{c}15056(80.66 \%) \\
1147(78.4 \%)\end{array}$ & $\begin{array}{c}2253(12.07 \%) \\
194(13.26 \%)\end{array}$ & $\begin{array}{l}522(2.8 \%) \\
35(2.39 \%)\end{array}$ & $\begin{array}{l}645(3.46 \%) \\
63(4.31 \%)\end{array}$ & $\begin{array}{l}189(1.01 \%) \\
24(1.64 \%)\end{array}$ \\
\hline $\begin{array}{l}\text { Combined } \\
\text { phenotype }\end{array}$ & $\begin{array}{c}\text { Total } \\
\text { missense pLOF FAF }\end{array}$ & $\begin{array}{c}18665 \\
1463(7.8 \%)\end{array}$ & $\begin{array}{l}14578(78.1 \%) \\
1117(76.35 \%)\end{array}$ & $\begin{array}{l}2725(14.6 \%) \\
223(15.24 \%)\end{array}$ & $\begin{array}{l}522(2.8 \%) \\
35(2.39 \%)\end{array}$ & $\begin{array}{l}635(3.4 \%) \\
59(4.03 \%)\end{array}$ & $\begin{array}{l}205(1.1 \%) \\
29(1.98 \%)\end{array}$ \\
\hline
\end{tabular}

The number and proportion for each phenotype is shown for those with a pathogenic or likely pathogenic variant by the missense pLOF FAF filtering strategy and in the total study population for comparison. 
Table 3. Demographic and clinical characteristics of the overall study population, putative pathogenic variant carriers $(\mathbf{G +})$, and those without any putative pathogenic variants in DCMassociated genes (G-) for the primary variant filtering strategy.

\begin{tabular}{|c|c|c|c|c|}
\hline & & \multicolumn{3}{|c|}{ missense pLOF FAF } \\
\hline & Overall & G- & $\mathrm{G}+$ & $\mathrm{P}$ \\
\hline $\mathrm{N}$ & 18665 & 17202 & 1463 & \\
\hline Female, $\mathrm{n}(\%)$ & $9844(52.7)$ & $9076(52.8)$ & $768(52.5)$ & 0.866 \\
\hline Age at recruitment, yrs & $54.96(7.50)$ & $54.94(7.49)$ & $55.16(7.56)$ & 0.283 \\
\hline Age at last follow up, yrs & $64.38(7.47)$ & $64.37(7.46)$ & $64.53(7.58)$ & 0.436 \\
\hline $\begin{array}{l}\text { Systolic BP automated reading } \\
(\mathrm{mmHg}) \text {, mean }(\mathrm{SD})\end{array}$ & $136.75(18.66)$ & $136.75(18.67)$ & $136.67(18.48)$ & 0.866 \\
\hline $\begin{array}{l}\text { Diastolic BP automated reading } \\
(\mathrm{mmHg}) \text {, mean (SD) }\end{array}$ & $81.25(10.37)$ & $81.27(10.39)$ & $81.09(10.14)$ & 0.544 \\
\hline Body mass index $\left(\mathrm{kg} / \mathrm{m}^{2}\right)$ & $26.51(4.16)$ & $26.51(4.17)$ & $26.53(4.07)$ & 0.873 \\
\hline Body surface area $\left(\mathrm{m}^{2}\right)$ & $1.86(0.21)$ & $1.86(0.21)$ & $1.86(0.21)$ & 0.865 \\
\hline Creatinine $(\mu \mathrm{mol} / \mathrm{L})$ & $72.12(14.09)$ & $72.11(14.06)$ & $72.31(14.45)$ & 0.601 \\
\hline Dead, n (\%) & $221(1.2)$ & $204(1.2)$ & $17(1.2)$ & 1 \\
\hline Age at death, yrs & $70.73(6.71)$ & $70.64(6.77)$ & $71.80(5.98)$ & 0.493 \\
\hline Coronary artery disease, $\mathrm{n}(\%)$ & $846(4.5)$ & $778(4.5)$ & $68(4.6)$ & 0.876 \\
\hline Heart failure, $\mathrm{n}(\%)$ & $240(1.3)$ & $210(1.2)$ & $30(2.1)$ & 0.01 \\
\hline Early DCM features, n (\%) & & & & 0.14 \\
\hline Arrhythmia and/or CCD & $2729(14.6)$ & $2505(14.6)$ & $224(15.3)$ & \\
\hline Isolated ventricular dilatation & $522(2.8)$ & $487(2.8)$ & $35(2.4)$ & \\
\hline $\begin{array}{l}\text { Hypokinetic non-dilated } \\
\text { cardiomyopathy }\end{array}$ & $645(3.5)$ & $582(3.4)$ & $63(4.3)$ & \\
\hline DCM overall, $\mathrm{n}(\%)$ & $205(1.1)$ & $176(1.0)$ & $29(2.0)$ & 0.00073 \\
\hline Subclinical DCM & $189(1.0)$ & $165(1.0)$ & $24(1.6)$ & \\
\hline Clinical DCM & $19(0.1)$ & $14(0.1)$ & $5(0.3)$ & \\
\hline LVESV (ml) & $63.46(63.75)$ & $63.50(65.77)$ & $62.92(31.60)$ & 0.737 \\
\hline LVEDV (ml) & $140.72(136.83)$ & $140.91(141.97)$ & $138.57(43.22)$ & 0.53 \\
\hline $\operatorname{LVEF}(\%)$ & $55.67(6.62)$ & $55.69(6.60)$ & $55.39(6.81)$ & 0.094 \\
\hline Hypertension, $\mathrm{n}(\%)$ & $6028(32.3)$ & $5574(32.4)$ & $454(31.0)$ & 0.295 \\
\hline Stroke, $\mathrm{n}(\%)$ & $330(1.8)$ & $301(1.7)$ & $29(2.0)$ & 0.586 \\
\hline Valvular heart disease, $\mathrm{n}(\%)$ & $527(2.8)$ & $487(2.8)$ & $40(2.7)$ & 0.894 \\
\hline Atrial fibrillation/flutter, n (\%) & $832(4.5)$ & $765(4.4)$ & $67(4.6)$ & 0.865 \\
\hline Bradyarrhythmia, n (\%) & $352(1.9)$ & $323(1.9)$ & $29(2.0)$ & 0.856 \\
\hline Cardiac conduction defect, $\mathrm{n}(\%)$ & $2448(13.1)$ & $2238(13.0)$ & $210(14.4)$ & 0.155 \\
\hline Sick sinus syndrome, $\mathrm{n}(\%)$ & $19(0.1)$ & $17(0.1)$ & $2(0.1)$ & 0.993 \\
\hline CIED, n $(\%)$ & $148(0.8)$ & $133(0.8)$ & $15(1.0)$ & 0.373 \\
\hline Pre-excitation syndrome, n (\%) & $35(0.2)$ & $32(0.2)$ & $3(0.2)$ & 1 \\
\hline Ventricular arrhythmia, n (\%) & $69(0.4)$ & $62(0.4)$ & $7(0.5)$ & 0.624 \\
\hline eGFR $\left(\mathrm{ml} / \mathrm{min} / 1.73 \mathrm{~m}^{2}\right)$ & $87.32(16.24)$ & $87.34(16.36)$ & $87.10(14.82)$ & 0.609 \\
\hline $\mathrm{CKD} \geq 3, \mathrm{n}(\%)$ & $396(2.2)$ & $365(2.2)$ & $31(2.2)$ & 1 \\
\hline
\end{tabular}

$\mathrm{BP}=$ blood pressure; $\mathrm{DCM}=$ dilated cardiomyopathy; $\mathrm{CCD}=$ cardiac conduction disease; $\mathrm{CIED}=$ cardiac implantable electronic device (including single- and dual-chamber permanent pacemaker, implantable cardioverter defibrillator, cardiac resynchronization therapy); $\mathrm{CKD}=$ chronic kidney disease; eGFR = estimated glomerular filtration rate; LVEDV = left ventricular end diastolic volume; LVESV = left ventricular end systolic volume; LVEF = left ventricular ejection fraction; SD = standard deviation. 
medRxiv preprint doi: https://doi.org/10.1101/2021.11.22.21266651; this version posted November 24, 2021. The copyright holder for this preprint (which was not certified by peer review) is the author/funder, who has granted medRxiv a license to display the preprint in perpetuity.

It is made available under a CC-BY-NC-ND 4.0 International license .

Table 4. Clinical and subclinical phenotype in participants with putative pathogenic variants in DCM genes according to the pLOF missense FAF classification, stratified based on geneevidence class. $^{1}$

\begin{tabular}{|c|c|c|c|c|c|}
\hline & $\begin{array}{l}\text { Definitive/ } \\
\text { Strong }\end{array}$ & Limited & Moderate & p-value* & p-value $* *$ \\
\hline $\mathrm{N}$ of participants, $\mathrm{n}(\%)$ & 608 & 770 & 85 & & \\
\hline Clinical phenotype, n (\%) & & & & 0.133 & 0.029 \\
\hline Phenotype negative & $568(93.4)$ & $726(94.3)$ & $80(94.1)$ & & \\
\hline Arrhythmia and/or CCD & $35(5.8)$ & $44(5.7)$ & $5(5.9)$ & & \\
\hline Dilated cardiomyopathy & $5(0.8)$ & $0(0.0)$ & $0(0.0)$ & & \\
\hline Subclinical phenotype (ECG + CMR), n (\%) & & & & 0.542 & 0.488 \\
\hline Phenotype negative & $480(78.9)$ & $601(78.1)$ & $66(77.6)$ & & \\
\hline Arrhythmia and/or CCD & $74(12.2)$ & $109(14.2)$ & $11(12.9)$ & & \\
\hline Isolated ventricular dilatation & $12(2.0)$ & $22(2.9)$ & $1(1.2)$ & & \\
\hline Hypokinetic non-dilated cardiomyopathy & $31(5.1)$ & $28(3.6)$ & $4(4.7)$ & & \\
\hline Dilated cardiomyopathy & $11(1.8)$ & $10(1.3)$ & $3(3.5)$ & & \\
\hline Combined phenotype, n (\%) & & & & 0.449 & 0.337 \\
\hline Phenotype negative & $468(77.0)$ & $584(75.8)$ & $65(76.5)$ & & \\
\hline Arrhythmia & $85(14.0)$ & $126(16.4)$ & $12(14.1)$ & & \\
\hline Isolated ventricular dilatation & $12(2.0)$ & $22(2.9)$ & $1(1.2)$ & & \\
\hline Hypokinetic non-dilated cardiomyopathy & $27(4.4)$ & $28(3.6)$ & $4(4.7)$ & & \\
\hline Dilated cardiomyopathy & $16(2.6)$ & $10(1.3)$ & $3(3.5)$ & & \\
\hline
\end{tabular}

$\mathrm{CCD}=$ cardiac conduction disease.

${ }^{1}$ For the purpose of analysis, patients with $>1$ putative pathogenic variants in genes classified in different evidence categories were considered in the higher evidence category. 
medRxiv preprint doi: https://doi.org/10.1101/2021.11.22.21266651; this version posted November 24, 2021. The copyright holder for this preprint (which was not certified by peer review) is the author/funder, who has granted medRxiv a license to display the preprint in perpetuity.

It is made available under a CC-BY-NC-ND 4.0 International license .

A

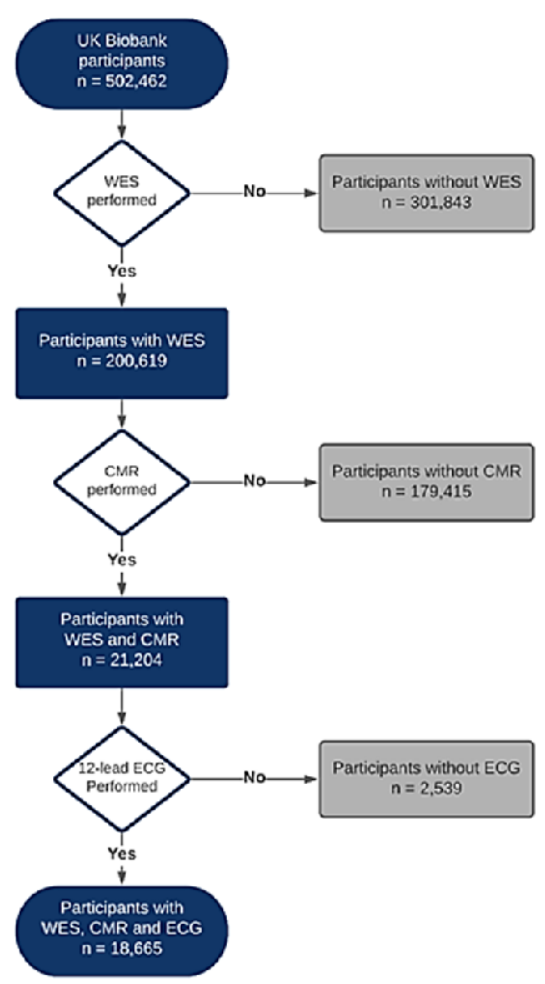

B

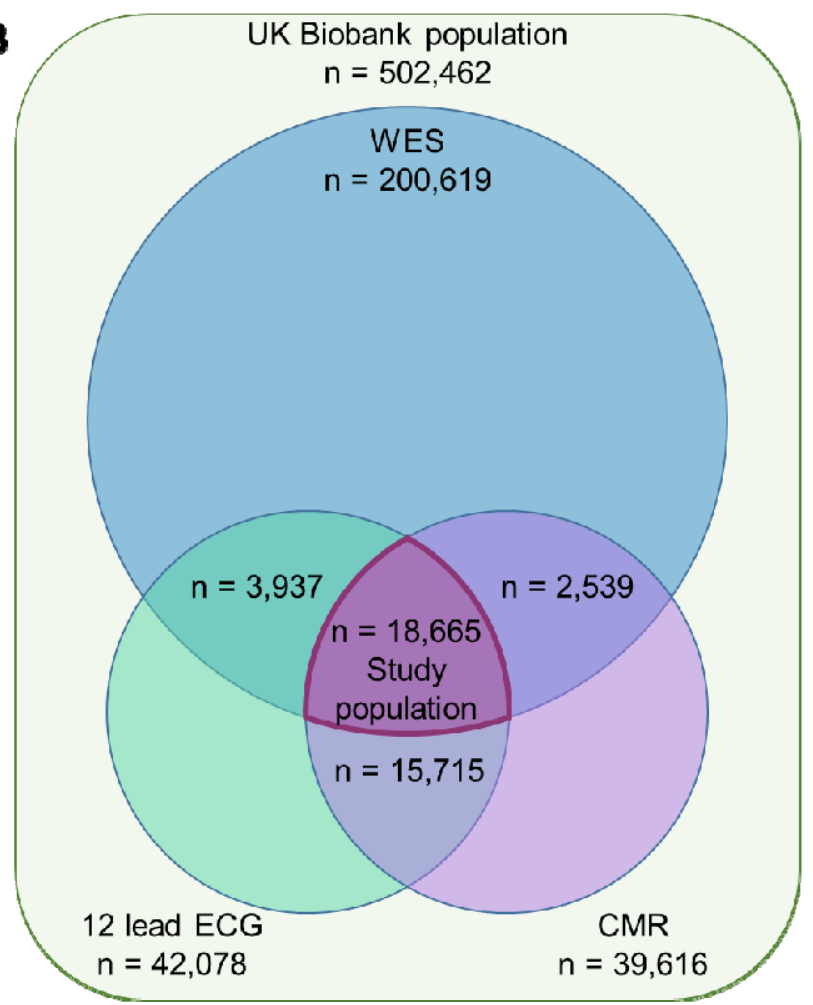

Figure 1. Study population selection criteria.

A, Flowchart demonstrates the sequential inclusion/exclusion criteria for the study population. B, Venn diagram showing the number of participants within the whole UK Biobank population with whole exome sequencing (WES), 12-lead ECG, and cardiac magnetic resonance (CMR) imaging. 


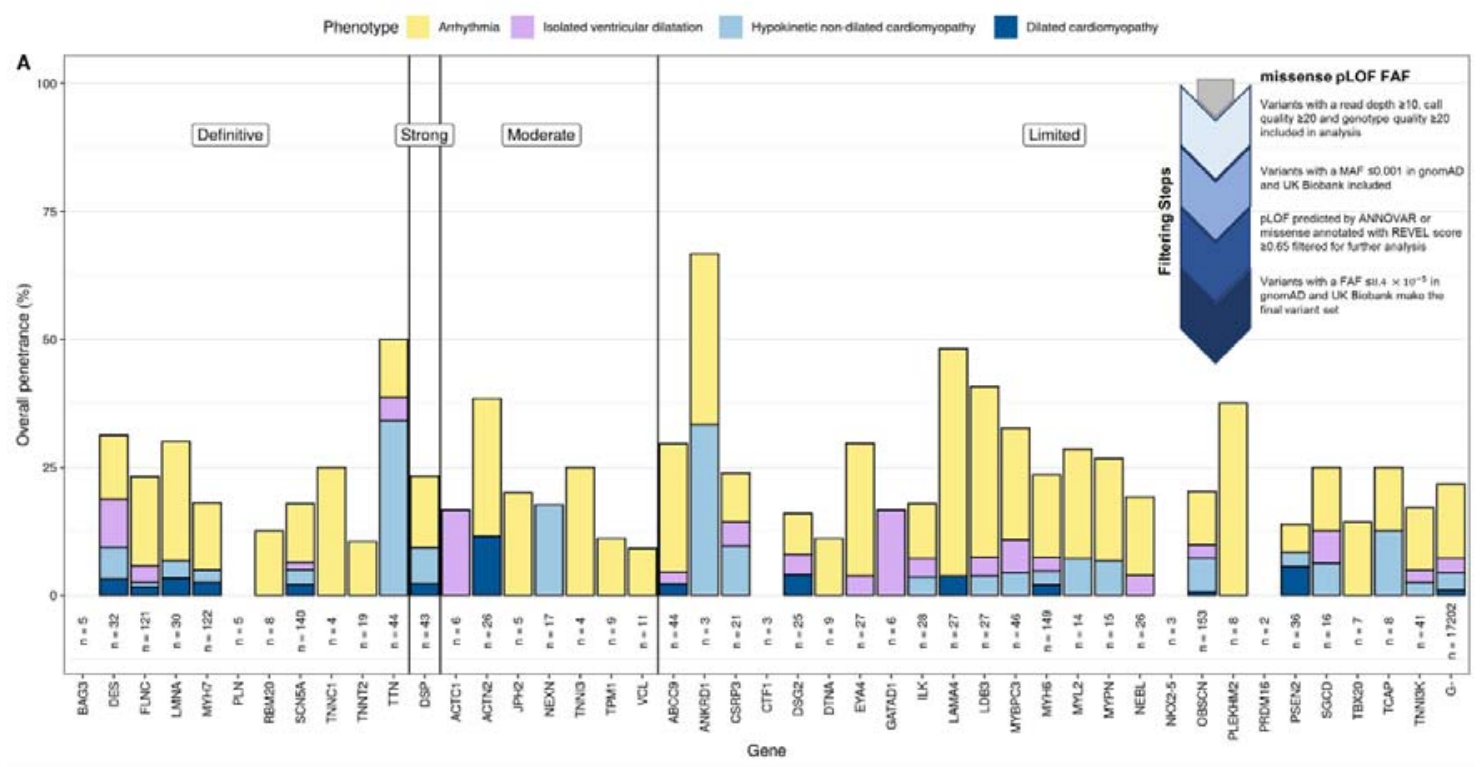

Figure 2. Clinical and subclinical penetrance of putative pathogenic variants DCM-associated genes in middle and older aged adults.

For each DCM-associated gene, the height of the bar indicates the percentage of pathogenic/likely pathogenic variant carriers, by missense pLOF FAF filtering strategy, with the specified phenotypes. Total number of participants with a pathogenic/likely pathogenic variant for each DCM-associated gene is indicated below the bar. The phenotype prevalence in those without a pathogenic or likely pathogenic mutation is shown on the far right (labelled "G-“"). Genes are categorized according to the strength of evidence determined by the ClinGen DCM gene curation expert panel and ordered alphabetically within each category. 

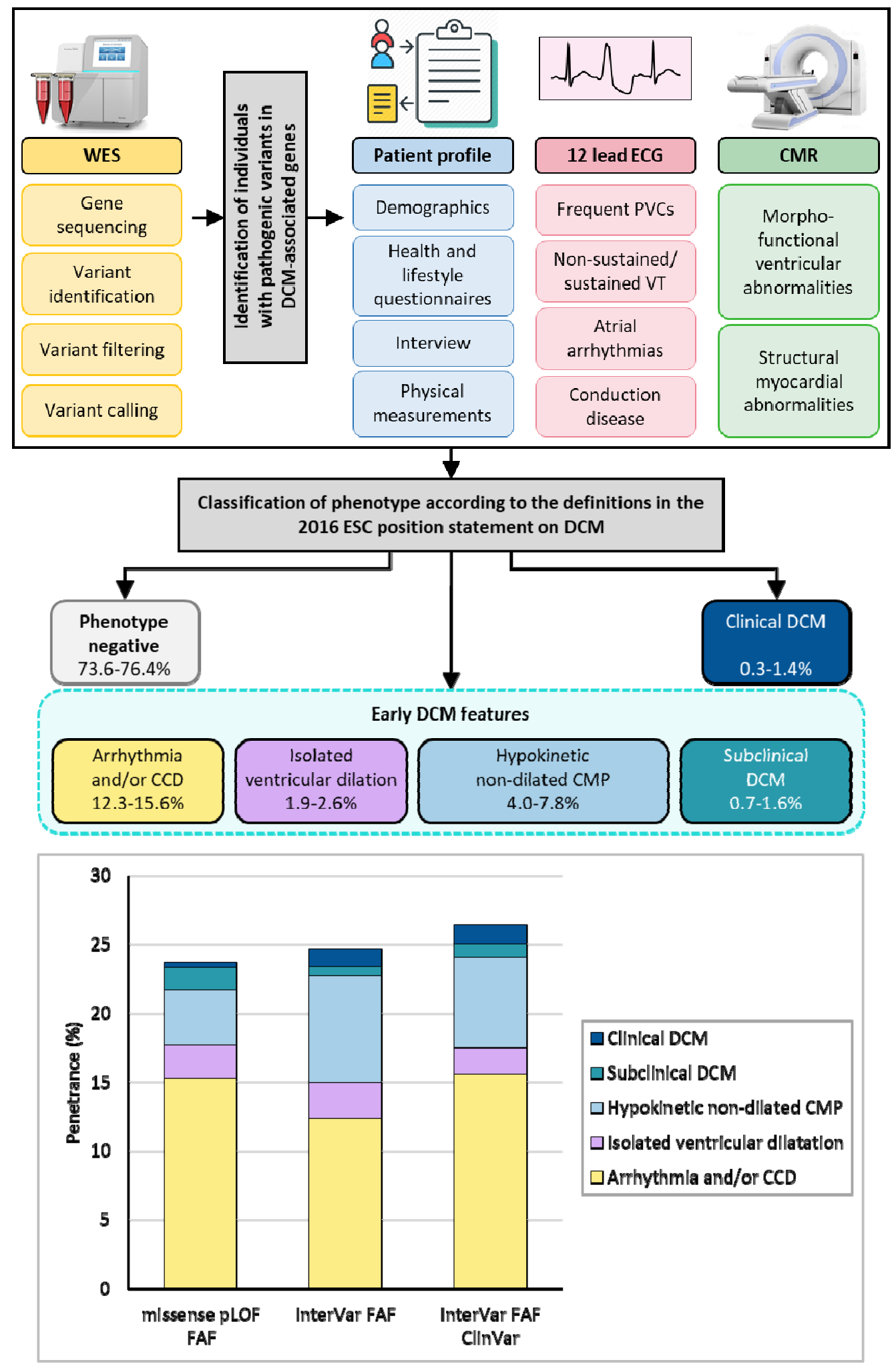

Figure 3. Central illustration of the study, demonstrating the methodology used for phenotype ascertainment, classification and clinical/subclinical phenotype in participants with putative pathogenic variants in DCM genes according to the three variant filtering strategies applied. 